\title{
Article \\ Voting at National versus European Elections: An Individual Level Test of the Second Order Paradigm for the 2014 European Parliament Elections
}

\author{
Hajo G. Boomgaarden, David Johann and Sylvia Kritzinger * \\ Department of Methods in the Social Sciences, University of Vienna, 1010 Vienna, Austria; E-Mails: \\ Hajo.Boomgaarden@univie.ac.at (H.G.B.), david.johann@univie.ac.at (D.J.), sylvia.kritzinger@univie.ac.at (S.K.) \\ * Corresponding author
}

Submitted: 6 October 2015 | Accepted: 23 December 2015 | Published: 29 February 2016

\begin{abstract}
The second-order paradigm is the dominant framework for research on electoral behavior in European Parliament (EP) elections. In this study, we assess to what degree voting patterns in the 2014 EP election were characterized by secondorderness. While most studies of second-order voting behavior rely on macro-level accounts or suffer from potentially conflated vote measures, this study relies on panel data from the 2013 national and the 2014 EP election in Austria. We study change patterns in electoral behavior and, more importantly, assess the motives behind differences in vote choices between first- and second-order elections. Overall, the findings point towards a persisting relevance of the second-order framework for explaining voting in the 2014 EP election.
\end{abstract}

\section{Keywords}

EU attitudes; EP election; panel study; second-order election

Issue

This article is part of the issue "How Different Were the European Elections of 2014?", edited by Wouter van der Brug, Katjana Gattermann and Claes de Vreese (University of Amsterdam, The Netherlands).

(C) 2016 by the authors; licensee Cogitatio (Lisbon, Portugal). This article is licensed under a Creative Commons Attribution 4.0 International License (CC BY).

\section{Introduction}

European Parliament (EP) elections have generally been described as second-order elections (Reif \& Schmitt, 1980, 1997). Compared to first-order elections - usually national (parliamentary) elections - less is at stake in second-order elections as the composition of the national government is not being determined. Compared to first-order elections, second-order elections are characterized by (e.g., Reif \& Schmitt, 1980): (1) lower turnout, (2) higher success rates for fringe and new parties, (3) electoral losses for government parties, (4) a higher percentage of invalid ballots, (5) issues and actors dominating the electoral campaign that are not at stake and do not stand for election, and (6) lower media attention. Classifying EP elections as second-order has prompted extensive academic attention, confirming by and large the assumptions of the second-order paradigm, ranging from a focus on party campaigns and campaign strategies (e.g., de Vreese, 2009), the coverage of mass media (e.g., Wilke \& Reinemann, 2007) to-most importantly-the behavior of voters (e.g., Hobolt, Spoon, \& Tilley, 2009; Hix \& Marsh, 2007, 2011).

There are good reasons, however, to speculate that the 2014 EP election was different from previous EP elections and therefore does not adhere anymore, or at least to a lesser degree, to the characteristics of a second-order election. First, the election took place during a deep crisis of European integration. As a consequence of the economic and financial crisis starting in 2008, the EU underwent what some called a "Euro crisis" with Greece at its center. Such a crisis of one of the most visible successes of European integration, the common currency, was likely to place the 2014 EP election high on the political and public agenda. Further- 
more, for the first time ever, most EP party groups campaigned with a EU wide candidate for the presidency of the Commission, with the race culminating between Junker (Christian Democrats) and Schulz (Social Democrats). These leading candidates had the objective to run a rather European focused campaign and to frequently discuss European issues (e.g., Piedrafita \& Renman, 2014). ${ }^{1}$ Therefore, it is important to reevaluate the assumptions generated by the secondorder literature for the case of the 2014 EP election (see Schmitt, 2005, p. 669).

This study examines whether voter behavior in the 2014 EP election is in line with assumptions surrounding second-order elections and seeks to answer the question if the 2014 election can (still) be described as a second-order election, despite a very different context to previous EP elections. First, we examine citizens' turnout and voting patterns between first- order national and second-order EP elections. Second, we analyze the motivations for changes in citizens' electoral behavior between national and EP elections, focusing in particular on the less-is-at-stake argument and on varying political involvement among the electorate. Only by uncovering the motivations behind voting patterns can we evaluate to what extent the second-order election paradigm is (still) valid. Unlike previous studies, we draw on a unique online panel survey database of Austrian voters surveyed during both national and EP election periods. This allows us to assess whether citizens indeed behave differently in first- versus second-order elections. By doing so, not only do we obtain a better insight into the behavior of individuals at different types of elections, we are also able to extend the literature on second-order elections.

\section{EP Elections as Second-Order}

All elections are equal, but some elections are more equal than others, so it appears. When comparing elections at different levels, the yardstick is most commonly the national election, labeled first-order election. Other elections at the local, regional or supranational level are juxtaposed against this yardstick, and referred to as second-order elections (Reif, 1984). The differences between these and first-order elections are said to be wide-ranging: they manifest themselves in the party campaigns, the mass media coverage of and the voters' engagement with the campaigns, as well as in the polling booths. While previous research has dealt with the second-order phenomenon in regard to local or regional elections (e.g., McAllister, 2004; Freire, 2004; Schakel \& Jeffery, 2013) in this study the focus is on European elections and campaigns.

In their seminal contribution, Reif and Schmitt

${ }^{1}$ See also van der Brug, Gattermann and de Vreese (2016) for the uniqueness of the $2014 \mathrm{EP}$ election.
(1980) provide the basic framework for the secondorder paradigm of EP elections. Based on the contention that the most important political decisions are made in the national political systems, it is argued that EP elections have to be viewed as second-order to national elections. Reif and Schmitt outline five dimensions that characterize second-order elections, of which the first, the 'less at stake dimension' (p. 9) has received most attention and has provided the central assumptions most often used when studying secondorder voting behavior (e.g., Reif, 1984; Schmitt, 2005). ${ }^{2}$ In short, these assumptions refer to patterns in turnout and voting behavior that should be characteristic of EP elections, provided they are real second-order elections. First, because there is less at stake in EP elections and due to a less politicized campaign, it is predicted that turnout will be lower in EP elections compared to the national level. Second, since government parties are in a position in which they may disappoint voters to a greater extent than opposition parties, it is likely that such dissatisfied voters will use the EP election as an easy opportunity to punish government parties. This translates into a higher likelihood of lower support for government parties in EP elections than in the previous national election. Third, it is argued that voters might cast more sincere ballots in elections in which less is at stake, since incentives to vote strategically are lower. Strategically it often makes more sense to vote for a big party since these have a higher likelihood of actually influencing political decisions. This 'voting with the heart' rather than 'voting with the head' phenomenon (Schmitt, 2005, p. 652; van der Eijk, Franklin, \& Marsh, 1996) would also translate into big parties loosing support in EP elections compared to national elections. A supplementary assumption that follows from this is that new and more extreme parties in particular would do comparatively well at EP elections (Reif, 1984; van der Eijk et al., 1996). ${ }^{3}$

The three central assumptions have been repeatedly tested and largely confirmed over the past three decades, in particular concerning turnout patterns (e.g. Curtice, 1989; Niedermayer, 1990; Reif, 1984). ${ }^{4}$ In a

\footnotetext{
2 The other dimensions are 'specific arena', 'institutionalprocedural', 'campaign' and 'main-arena political change' (Reif \& Schmitt, 1980, pp. 10-15). Some of these provide additional impetus to the basic postulates of the 'less at stake' dimension. ${ }^{3}$ Another important contention in the literature is that the electoral cycle matters and patterns differ between countries depending on when in the national electoral cycle the EP elections are held. Since this study looks at voting in a single country only, we do not further discuss this issue here.

${ }^{4} \mathrm{~A}$ further contention of the second-order paradigm stretches to the wider campaign context. Allegedly, EP elections are characterized by little attention from the mass media and less active party campaigns. Furthermore, EP election campaigns are said to be dominated by national, not European perspec-
} 
comprehensive contribution after the first four EP elections, Marsh (1998) finds substantial support for expected vote choice patterns: government parties as well as bigger parties had been losing out in EP elections. Looking at the 2004 EP elections, Schmitt (2005) still finds strong signs for second-order voting throughout Western European countries, less so in the then new member states of Central and Eastern Europe. By and large, and in particular in Western countries, turnout was lower, government parties were losing and small parties were winning in EP elections. In a similar vein, Koepke and Ringe (2006) conclude that the applicability of the second-order framework to the Central and Eastern European countries would be at least questionable. Träger (2015), however, finds that the EP election of 2014 was again characterized by strong indications of second-orderness, with low participation rates, strong 'anti-government swings' and more support for small and new parties across Europe.

Such largely aggregate-level perspectives allow for speculation about individual differences, while empirically testing the possible motivations at the individuallevel and gaining insight in differences in voters' behavior at first- and second-order elections is not possible (Schmitt, 2005, is an exception here). Individual-level data are needed to further test the theoretical backgrounds behind the second-order framework (e.g., van Aelst \& Lefevere, 2012; see also Giebler \& Wagner, 2015, for a more elaborate argumentation).

Only few studies explicitly consider motivations for turnout differences between national and EP elections at the individual level. While a vast range of literature deals with explanations of turnout in general terms (see Blais, 2006), a considerable number has specifically focused on turnout at EP elections. As with the general literature, a distinction is made between macrolevel systemic factors (such as compulsory voting, weekend voting etc.; see Mattila, 2003) and micro-level motivations. As our analysis is confined to a single country context, macro-level factors are not further discussed here, ${ }^{5}$ except for the second-order framework influencing micro-level motivations. Research on possible individual-level predictors of turning out in EP elections has provided mixed results. It is assumed that citizens' perceptions of the EU polity (for instance trust in the EP or the EU in general) function as explanatory

tives, thus show strong domestification in terms of issues and actors (e.g., Brunsbach, John, \& Werner, 2012; Cushion \& Thomas, 2015; de Vreese, 2003, 2009; Tenscher \& Maier, 2009; Wilke \& Reinemann, 2007). Regarding media campaign coverage, it needs to be noted, however, that there are strong crossnational and cross-media differences and that some have identified a steady increase in the visibility of EP elections (e.g., Boomgaarden \& de Vreese, 2016). We do not further discuss these issues here.

${ }^{5}$ See Hobolt et al. (2009) and Söderlund et al. (2011) for studies integrating context and individual factors. factors for voter turnout. Schmitt and Mannheimer (1991) however only find small effects of EU factors, while Blondel, Sinnott and Svensson (1997) come to the opposite conclusion (see also Flickinger \& Studlar, 2007, for macro-level support).

While EU attitudes are one plausible motivation for turnout at EP elections, it has been argued that involvement and information play an important role as well (de Vreese \& Tobiasen, 2007; Mattila, 2003). Political interest, for instance, has been shown to consistently affect turnout in general (e.g., Denny \& Doyle, 2008) and also in EP elections (van der Eijk \& Oppenhuis, 1990). Söderlund, Wass and Blais (2011) explicitly address the role of political interest in a secondorder framework. They argue and demonstrate that, as EP elections are of low salience, political interest plays an even greater role for turnout in EP than in national elections. Our analysis continues along those lines by additionally focusing on attention to the campaign. Even if of low salience generally, individuals' attentiveness to the EP campaign may increase their propensity to cast a vote, simply because they are more aware of what is going on in the campaign. This may in particular be true for the 2014 campaign in which the apparent horse race between the two main candidates may have motivated people to vote.

In this study we address three motivations for changing voting behavior between national and EP elections. Two of these are in line with the secondorder framework, while the third deviates from this framework. First, as mentioned above, voters may use the EP elections to display their true preferences. Since there is something at stake in national elections, voters are more inclined to vote strategically, that is for bigger parties that are more likely to enter government and influence policy. Voters in these elections thus depart from their preferences and cast a vote for a party that would otherwise not be their first choice. In EP elections, by contrast, as less is at stake, voters are more likely to display their true preference when casting a vote. Vote choice is more expressive; voters tend to 'vote with their hearts' (e.g., Carrubba \& Timpone, 2005; Franklin \& Wlezien, 1997; Marsh, 1998; Reif \& Schmitt, 1980). Prior studies have found some empirical evidence for this assumption on the individual level, while at the same time it also appears that sincere, expressive voting is not the only mechanism at play (Carrubba \& Timpone, 2005).

A second motivation (that would lead to a similar outcome as the sincere voting assumption discussed above) is that voters use the EP election to demonstrate discontent with national politics, in particular the national government (Franklin, van der Eijk, \& Marsh, 1995; van der Eijk \& Franklin, 1996). Since there is apparently little at stake in EP elections, voters may use these elections as a kind of referendum to send signals of dissatisfaction to the national government. 
Voters may 'vote with their boots' and punish the incumbents without this punishment having much consequence for the composition of the national government, thus being a safe opportunity to send signals. Again, there is limited support for this assumption at the individual-level (e.g., Carrubba \& Timpone, 2005).

The third motivation under study here departs from the second-order framework in that it puts voters' actual perceptions of EU politics and policies center stage. This 'EU matters' motivation assumes that voters have knowledge of what is happening at the EUlevel and take into account which of the parties would best represent their perceptions of EU politics when casting a vote in EP elections. In this framework we should see that vote change should be a function of voters' perceptions of and attitudes towards EU politics. Studies of voting behavior at EP elections have shown that, at least under certain circumstances, the EU does indeed matter for voting decisions (Carrubba \& Timpone, 2005; Heath, McLean, Taylor, \& Curtice, 1999; Hobolt et al. 2009; van Aelst \& Lefevere, 2012; Clark \& Rohrschneider, 2009; for conflicting evidence see Giebler \& Wagner, 2015). As such, EP elections cannot only be considered as second-order elections any longer. While our study does not address the differential strengths of EU attitudes as motivation for voting behavior at different elections, we specifically look at EU attitudes being a motivation to change one's vote from national to EP elections. We draw on the three assumptions discussed here when formulating our hypotheses.

A major shortcoming of prior studies that focus on electoral behavior at national and EP elections is that their results are based first and foremost on potentially incorrect recall questions. ${ }^{6}$ When survey respondents are asked about their electoral behavior for different elections in the same survey, it is highly likely that their responses are biased because respondents tend to harmonize their responses. Our study is different in that it employs panel data in which the same individuals were probed about their electoral behavior right after the respective election took place.

\section{Hypotheses}

To test whether the individual vote choice at the 2014 EP election differed from the voting behavior of the same individuals at the previous national election in ways that are in line with presumptions from the second order literature, we formulate the following hypotheses. These are drawn from the host of literature reviewed above regarding the patterns of second-order as opposed to first-order election behavior. Since we can only speculate so far about possible changes brought about by the 2014 context, we adhere to for-

\footnotetext{
${ }^{6}$ However, for an exception see van Aelst and Lefevere (2012).
}

mulating assumptions similar to many prior studies, based on observations during past EP elections (e.g., Koepke \& Ringe, 2006; Marsh, 1998; Schmitt, 2005). These will form the basis for the subsequent hypotheses regarding individual motivations for the differences in voting behavior. With regard to turnout we expect:

$\mathrm{H} 1$ : Voters are more likely to abstain at European elections compared to national elections.

Concerning patters of vote choice we follow prior studies in differentiating between votes for government parties and for bigger parties generally, vis-à-vis votes for opposition parties and for smaller parties. Since the political configuration in Austria in 2014 makes it impossible to distinguish between government and big, or opposition and small parties respectively, we refrain from formulating two different hypotheses here. The two major parties were in a grand coalition, and the smaller parties formed the opposition (as has mostly been the case in post-war Austria).

H2a: Voters are more likely to switch vote from a (large) government party in the national election to a (small) opposition party in the EP election than vice versa.

While the 'voting with the heart' thesis would predict vote switching from government to opposition parties, the 'voting with the boot' or protest vote thesis would allow for two different patters which are subject of the following hypothesis. To protest against the government, government supporters at the national election could just simply stay home during the EP election. Therefore we expect:

$\mathrm{H} 2 \mathrm{~b}$ : Voters of (large) government parties at national elections are more likely to abstain at the European election than voters of (small) opposition parties.

Beyond these comparative aggregate-level hypotheses we consider possible motivations of individual voters that would explain the differences in electoral behavior. Most of the extant individual-level literature on second-order voting focuses on actual vote choice, while we take both, motivations for turnout and motivations for vote swings into account. Starting with the former we have identified two main factors that may explain turnout differences between national and EP elections. First, EU attitudes are supposed to matter. In line with prior research (Blondel et al., 1997; de Vreese \& Tobiasen, 2007; Flickinger \& Studlar, 2007) we expect that positive attitudes towards European integration are positively related to turnout at the EP elections. 
H3: Positive attitudes towards European integration are positively related to turnout at the EP election.

Also in line with prior research (de Vreese \& Tobiasen, 2007; Sönderlund et al., 2011) we expect that involvement matters for turnout at EP elections.

$\mathrm{H} 4$ : Interest and involvement in politics are positively related to turnout at the EP election.

Our hypotheses of individual level motivations to change vote choice relate to the second-order framework in that they address the notions of 'voting with the heart' versus 'voting with the boot' and furthermore consider whether the 'EU matters' for vote switching. First, we assume that dissatisfaction with politics at the level of the nation state would lead voters to switch from voting for the big, governing parties to voting for a smaller, opposition party-they 'vote with their boots' by largely drawing on national political considerations.

H5: Dissatisfaction with national politics motivates those who voted for a (large) government party in the national election to vote for a (small) opposition party in the EP election.

An alternative perspective would be that vote switching between national and EP elections is actually an expression of voters' true preferences. Here we should see that voters' switching behavior can be explained by their political predispositions - they tend to vote with their heart.

H6: Vote switching between the national and the EP election is motivated by voters' political predispositions.

Finally, we depart from the second-order framework and examine-in line with earlier studies (Carrubba \& Timpone, 2005; van Aelst \& Lefevere, 2012)-whether vote switching between national and EP elections can be explained by EU policy perceptions and preferences. Since we study this motive in the context of secondorder elections, we primarily focus on EU policy preferences as a motive to switch vote from a bigger government party to a smaller opposition party. We should see dissatisfaction with politics on a European level as a motivator for voters to switch from the government to opposition parties in general terms. The opposition, in particular in the Austrian case of a center grand coalition, is diverse. In this case it is more likely that voters would not vote for any opposition party, but specifically for those opposition parties that take a clear anti-European position-thus we should see those dissatisfied with EU politics to cast a clear 'EU matters' vote.
H7a: Dissatisfaction with European politics motivates those who voted for a (large) government party in the national election to vote for a (small) opposition party in the EP election.

H7b: Dissatisfaction with European politics motivates those who voted for a pro-European party in the national election to vote for an antiEuropean party in the EP election.

\section{Data and Method}

We test our expectations within Austria, which joined the EU in 1995. While Austrian voters were supportive of joining the EU in a referendum in 1994 (66.6 per cent voted in favor of joining the EU), their overall support of the European integration process dropped substantially soon thereafter. Eurobarometer data reveal that Austrian citizens were and still are hardly convinced to have benefited from EU membership, and support for EU-membership was and still is only slightly higher than in the UK. Unsurprisingly, Austria has always had a number of rather Eurosceptic parties running in EP-elections, some of them being very successful over the course of the years (e.g. List Hans-Peter Martin and FPÖ (Freedom Party), together gained 30.4 per cent of the vote share in the 2009 EP election). Meanwhile, like in most European countries, the mainstream parties can overall be characterized as being pro-European. The two mainstream parties in Austria, the Social Democrats (SPÖ) and the Christian Democratic "Austrian People's Party" (ÖVP), are also government parties, as they have been in a grand coalition (again) since 2006.

For our analyses, we rely on a unique online panel study within the Austrian National Election Study (AUTNES) which collected data before and after the 2013 Austrian national election, as well as after the 2014 EP elections in Austria (Kritzinger et al., 2016). In particular, we use wave 4 of the panel study fielded immediately after the Austrian national election that took place in September 2013, and wave 5 collected in the aftermath of the EP elections in May 2014. 2.456 respondents took part in fourth wave of the online panel in 2013, of which 1.222 could be re-interviewed after the EP elections in 2014. Hence, the same respondents were interviewed after two different elections and this avoids the problem of having to rely on recall questions about past turnout behavior and vote choice which have been shown to be plagued by considerable errors (van der Eijk \& Niemöller, 2008; Waldahl \& Aardal, 2000; Weir, 1975): most importantly, it appears likely that responses with regard to two different elections taken in the same survey influence each other. In other words, responses about electoral behavior at $\mathrm{t}-1$ that are provided at $\mathrm{t}$ (where $\mathrm{t}$ could be either the national, first-order or the second-order EP 
election and $\mathrm{t}-1$ the respective opposite) might be faulty because respondents incorrectly remember their voting behavior or because they reflect current preferences at $t$. Individual differences identified on the basis of such data may therefore be rather hypothetical and hardly reflective of differences in real preferences at the two time points (Marsh \& Mikhaylov, 2008; van der Eijk \& Franklin, 1996).

We used respondents' electoral behaviors in 2013 and 2014 to construct our various dependent variables on which the outlined individual motivations on changes in electoral behavior between first- and secondorder elections were then tested. Concerning to turnout we came up with four categories of voters, two of them indicating change: (1) respondents who abstained from both elections; (2) respondents who participated only in the national election; (3) respondents that turned out only in EP elections; and (4) those respondents that participated both in the national and the EP elections.

With regard to vote choice, we also constructed several categories. First, we examined which party the respondent voted for in the national election and then created several outcome variables for 2014. Voters that took part in the EP elections could switch from (1) government parties in national elections to opposition parties in EP elections or from (2) opposition parties to government parties. The last two categories we coded were (3) respondents switching from pro-EU parties in national elections to Eurosceptic parties in EP elections and (4) respondents switching from Anti-EU parties in national elections to Pro-EU parties in EP elections. It should be noted that these categories are not exclusive, in that for instance a pro-EU party could also be a government party (see the notes below Table 2 for the concrete coding of the various parties).

Turning to the main independent variables, we examine four types of factors: satisfaction with national politics, satisfaction with European politics, political involvement and general political predispositions. First, to evaluate citizens' levels of satisfaction with the national political system in general and politics in particular we use three variables. The first one captures respondents' levels of satisfaction with democracy in Austria, the second citizens' satisfaction with the current Austrian government, and for the third, we use respondents' perception of the economic development in Austria over the last 12 months. Satisfaction with European politics is reflected in four items in total. Parallel to the national level, respondents reported their satisfaction with EU democracy, and additionally, we include respondents' satisfaction with political decisions at the EU level. We furthermore probed a general assessment of EU integration commonly used in EU public opinion studies (European integration should go further or has already gone too far) and, given the crisis of European integration in 2014, we also used a question on EU solidarity ("In times of crisis Austria should financially support EU member states that suffer from economic and financial distress").

For the turnout model, we captured political involvement using questions regarding respondents' attentiveness towards both the national and the EP election campaign. Furthermore, for all our models we rely on a traditional measure of political interest as an indicator for involvement. Finally, our measure of political predisposition is limited to ideological self-placement on a left-right scale and to the squared term of this measure to consider differential behavior of the ideological extremes. Eventually, we included a set of control variables, such as education, age and gender. While for our turnout hypotheses we run a multinominal logit model (in line with current standards we report marginal effects, computed according to the "observed-value-approach", Hanmer \& Kalkan, 2013), for the vote choice models we run several binary logit models.

\section{Results}

Addressing our first set of hypotheses, we first provide some descriptive results on turnout and voting behavior differences at the aggregate-level between the national and the EP election. Specifically, we examine whether and to what extent individuals are more likely to turn out at national elections and are more prone to vote for small and oppositions parties in EP elections. These results confirm our expectations based on the second-order framework to some degree (see Figure 1). Concerning turnout, we find that 24 per cent of the respondents voted in the national but not the EP election, while only less than two per cent did the reverse (differences significant at $p<.001$ ). We thus find clear indications of second-orderness of EP elections when it comes to turnout, supporting $\mathrm{H} 1$. When considering vote switching from government to opposition parties and vice versa, the picture is also quite clear, but somewhat less pronounced. Of those who voted for a government party at the national election, some 18 per cent switched to voting for an opposition party in the EP election, while less than ten per cent of those who cast a national election vote for an opposition party switched to a government party (difference significant at $p<.001$ ). This provides support for the second-order framework as expected in $\mathrm{H} 2 \mathrm{a}$.

The expectation, however, that those who voted for a government party at the national election were more likely to abstain in the EP election ( $\mathrm{H} 2 \mathrm{~b}$ ) was not confirmed. Taking as a baseline all those who cast a vote in the national election, only some ten per cent of the initial government voters, but 18 per cent of the opposition voters did not turn out at the EP election (difference significant at $\mathrm{p}<.001$ ). Voters did not punish government parties more than opposition parties by 


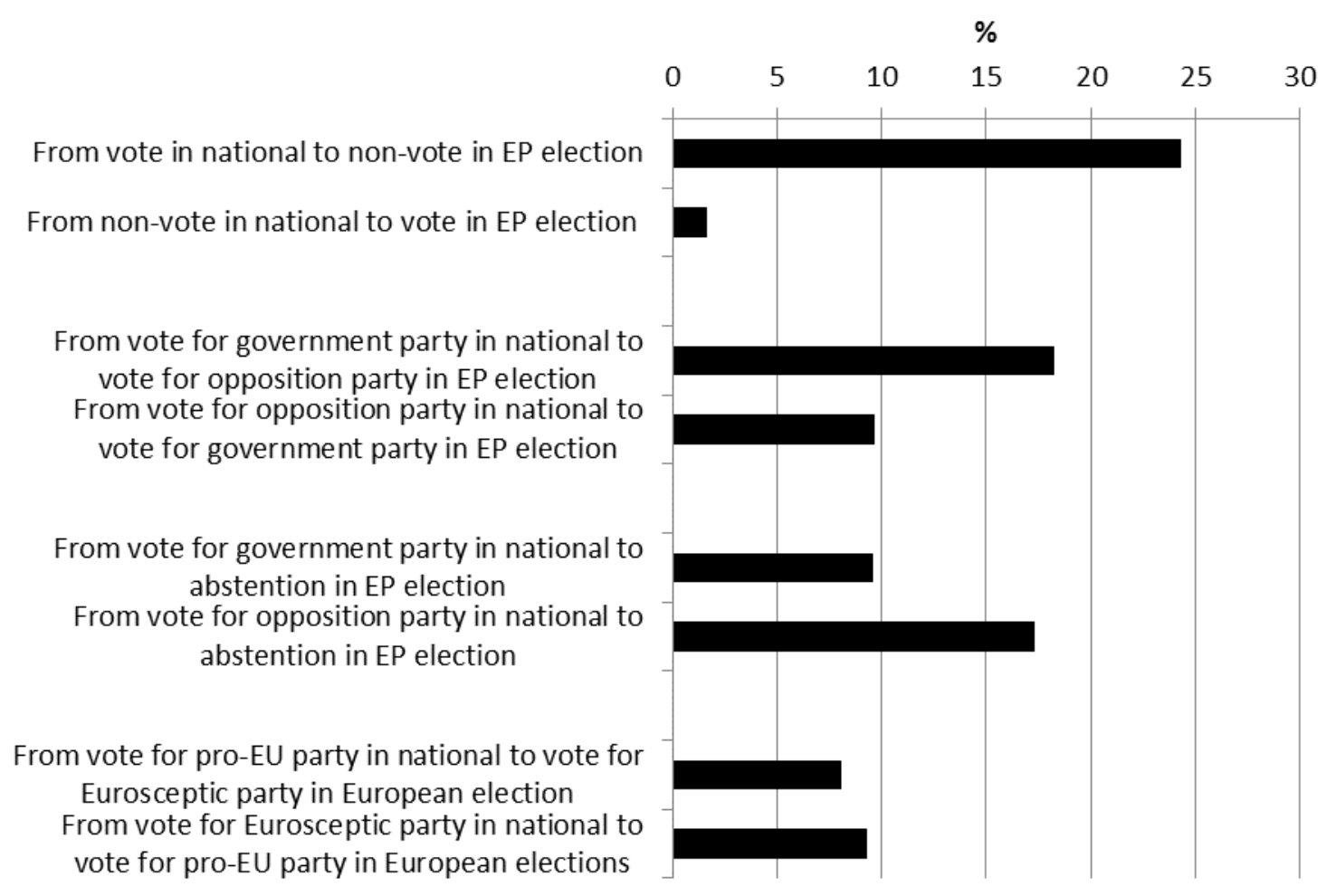

Figure 1. Aggregate patterns of changes in voting behavior.

not turning out, but rather the reverse. Finally, while not specifically hypothesized, we find no aggregatelevel evidence of an anti-EU party swing at the European election. Of all respondents who cast vote in both elections, only some eight per cent switched from a pro-EU party vote in the national election to a Eurosceptic party vote in the EP election, and another nine percent did the reverse (difference non-significant).

In a second step, we test the motives for different behaviors. The first set of analyses relates to turnout patterns between first- and second-order elections. In these explanatory models of turnout, we consider factors relating to involvement in politics and EU attitudes. We present the average marginal effects of these factors based on our MNL model in Table $1 .^{7}$ Starting with EU attitudes, the results show that retrospective satisfaction with EU decisions is positively related to turnout in both national and EP elections. Those few who only turned out at EP elections did not do so in relation to their EU attitudes. With regard to the political involvement variables, political interest is not related to turnout, and it is only negatively related to no turnout in both elections. Meanwhile, attention to the EP campaign is positively related to voting in both the national and the EP election and negatively to turnout in the general election only. While not explicitly hypothesized, we also find that it is in particular citizens placing themselves in the middle of the left-right

${ }^{7}$ See Table A3 in the Appendix for logit coefficients. scale that were more likely to turn out only in the general election, while citizens placing themselves at the edges of the left-right scale are more likely to turn out in both elections. ${ }^{8}$

Overall, we find some support for the assumption that EU attitudes are a motivation for turning out at EP elections ( $\mathrm{H3}$ ). Although considering the number of EU attitude variables employed in our model, it is striking to see that only very few of those factors actually matter. Nonetheless, it is comforting to see that none of our EU attitude variables are related to turnout at national elections only. Turnout cannot be explained by political interest. However, EP campaign attention is a strong positive predictor of turnout. We obtain rather mixed results for $\mathrm{H} 4$.

The second set of explanatory models considers changes in vote choice between the national and the EP election for different types of parties (Table 2). In line with the second-order framework, we focus on political predispositions, national protest motives, and, additionally, on EU attitudes. The first model, explaining vote switching from a (large) government party in the national to a (small) opposition party in the EP election, is in line with our expectation formulated in $\mathrm{H} 5$. Those who are discontent with the national government are more likely to switch from a government vote in the national to an opposition vote in the EP election. This we

8 This interpretation is based on illustrations that are available on request. 
Table 1. Average marginal effects.

\begin{tabular}{|c|c|c|c|c|}
\hline & $\begin{array}{c}\text { Turnout in No } \\
\text { Election }\end{array}$ & $\begin{array}{l}\text { Turnout Only in } \\
\text { General Election }\end{array}$ & $\begin{array}{l}\text { Turnout Only } \\
\text { in EP Election }\end{array}$ & $\begin{array}{c}\text { Turnout in Both } \\
\text { Elections }\end{array}$ \\
\hline \multirow[t]{2}{*}{ Age 16 to 29} & 0.03 & $0.08 \#$ & 0.04 & $-0.15^{* *}$ \\
\hline & $(0.03)$ & $(0.05)$ & $(0.03)$ & $(0.06)$ \\
\hline \multirow[t]{2}{*}{ Age 30 to 44} & 0.02 & 0.07 & $0.04 \#$ & $-0.13 * *$ \\
\hline & $(0.03)$ & $(0.04)$ & $(0.02)$ & $(0.04)$ \\
\hline \multirow[t]{2}{*}{ Age 45 to 59} & 0.03 & 0.03 & 0.02 & $-0.08 \#$ \\
\hline & $(0.03)$ & $(0.04)$ & $(0.02)$ & $(0.04)$ \\
\hline \multirow[t]{2}{*}{ Men } & 0.01 & $-0.06 *$ & -0.01 & $0.06 *$ \\
\hline & $(0.02)$ & $(0.03)$ & $(0.01)$ & $(0.03)$ \\
\hline \multirow[t]{2}{*}{ Education (Matura) } & $-0.04 *$ & $-0.06 \#$ & -0.00 & $0.10^{* *}$ \\
\hline & $(0.02)$ & $(0.03)$ & $(0.01)$ & $(0.03)$ \\
\hline \multirow[t]{2}{*}{ Interest in politics } & $-0.04 *$ & 0.02 & -0.01 & 0.03 \\
\hline & $(0.02)$ & $(0.03)$ & $(0.01)$ & $(0.04)$ \\
\hline \multirow[t]{2}{*}{ Satisfaction with democracy AT } & -0.02 & -0.01 & 0.00 & 0.03 \\
\hline & $(0.02)$ & $(0.03)$ & $(0.01)$ & $(0.03)$ \\
\hline \multirow[t]{2}{*}{ Satisfaction with democracy EU } & -0.04 & -0.05 & 0.01 & $0.08 \#$ \\
\hline & $(0.03)$ & $(0.04)$ & $(0.01)$ & $(0.04)$ \\
\hline \multirow[t]{2}{*}{ Satisfaction with government AT } & 0.01 & 0.06 & -0.01 & -0.05 \\
\hline & $(0.03)$ & $(0.04)$ & $(0.02)$ & $(0.05)$ \\
\hline \multirow[t]{2}{*}{ Satisfaction with decisions of EU (past 12 month) } & $-0.08 \#$ & -0.04 & -0.01 & $0.13^{*}$ \\
\hline & $(0.04)$ & $(0.04)$ & $(0.02)$ & $(0.05)$ \\
\hline \multirow[t]{2}{*}{ Assessment of European integration } & -0.00 & -0.00 & 0.00 & 0.00 \\
\hline & $(0.00)$ & $(0.01)$ & $(0.00)$ & $(0.01)$ \\
\hline \multirow[t]{2}{*}{ AT should support other EU members } & -0.00 & -0.01 & 0.00 & 0.01 \\
\hline & $(0.01)$ & $(0.02)$ & $(0.01)$ & $(0.02)$ \\
\hline \multirow[t]{2}{*}{ Changes in Economic Situation AT (past 12 month) } & 0.01 & 0.01 & $-0.02 *$ & -0.00 \\
\hline & $(0.01)$ & $(0.02)$ & $(0.01)$ & $(0.02)$ \\
\hline \multirow[t]{2}{*}{ Attentiveness to general election campaign } & $-0.03 \#$ & 0.03 & -0.01 & 0.01 \\
\hline & $(0.02)$ & $(0.03)$ & $(0.01)$ & $(0.04)$ \\
\hline \multirow[t]{2}{*}{ Attentiveness to EP election campaign } & -0.02 & $-0.18 * * *$ & 0.01 & $0.20 * * *$ \\
\hline & $(0.02)$ & $(0.03)$ & $(0.01)$ & $(0.03)$ \\
\hline
\end{tabular}

Note: Delta-method standard errors in parentheses; \# $p<.10,{ }^{*} p<.05,{ }^{*} p<.01,{ }^{* * *} p<.001 ;$ See Tables A1 and A2 in the Appendix for the variable coding; See Table A3 in the Appendix for logit coefficients.

take as an indication for a 'vote with the boot' in EP elections, much in line with the second-order framework. Neither ideological self-placement (predisposition), nor EU attitudes explain switching behavior. Although further specifications of vote switching shown in model three do provide a somewhat different picture. Changing votes from a pro-EU party in the national election to a Eurosceptic party is clearly influenced by EU attitudes. Dissatisfaction with EU decisions and negative assessments of EU integration explain this kind of switching behavior. Ideological predispositions and protest motives do not play a role here, giving a clear indication of an 'EU matters' framework (H7b). In sum, we identify protest motives as drivers of the typically postulated anti-government swing in EP elections. It is, however, important to specify vote switching behavior between certain types of parties in order to get at EU driven motives for differences in vote choice. It appears relevant to further specify the kind of party voters turn to when turning their back on the party they voted for in the national election.

Concerning vote switching, political predispositions and EU attitudes act as opposing drivers of the second- order framework (second and fourth model). Those at the ideological center with rather positive EU attitudes are more likely to switch from voting for an opposition or Eurosceptic party in the national, to a government party or a pro-EU party in the EP elections. With regard to $\mathrm{H} 6$, we find that political predispositions do not influence vote switches as predicted by the second-order framework, but rather in the opposite direction. Of the control variables, only one consistent finding is noteworthy. It is in particularly the young that tend to switch votes to (smaller) Eurosceptic opposition parties. Overall the models perform quite well, with RSquare values between .23 and .56 .

In sum, we find only partial evidence for our hypotheses in the data. Table 3 summarizes the findings presented above. As shown, slightly more than half our expectations, which were formulated in line with the second-order literature, found support, while we find only weak evidence in support of, or had to reject the other hypotheses. This suggests that the second-order phenomenon might at least not apply similarly in all cases, and that individual-level data are useful to specify and thoroughly investigate general assumptions. 
Table 2. Binary logit models explaining patterns in vote choice.

\begin{tabular}{|c|c|c|c|c|}
\hline & Gov. to Opp. & Opp. to Gov. ${ }^{1}$ & Pro-EU to Anti-EU² & Anti-EU to Pro-EU \\
\hline \multirow[t]{2}{*}{ Age 16 to 29} & $1.62 * *$ & -0.58 & $1.35^{*}$ & 1.62 \\
\hline & $(0.60)$ & $(0.63)$ & $(0.57)$ & $(0.99)$ \\
\hline \multirow[t]{2}{*}{ Age 30 to 44} & 0.84 & 0.10 & $1.14 *$ & 0.38 \\
\hline & $(0.54)$ & $(0.50)$ & $(0.50)$ & $(0.64)$ \\
\hline \multirow[t]{2}{*}{ Age 45 to 59} & 0.50 & 0.26 & 0.41 & 0.12 \\
\hline & $(0.43)$ & $(0.47)$ & $(0.45)$ & (0.59) \\
\hline \multirow[t]{2}{*}{ Men } & -0.49 & $-0.58 \#$ & 0.26 & 0.12 \\
\hline & $(0.36)$ & $(0.35)$ & $(0.35)$ & $(0.48)$ \\
\hline \multirow[t]{2}{*}{ Education (Matura) } & -0.24 & 0.51 & $-0.73 *$ & $1.33 * *$ \\
\hline & $(0.38)$ & $(0.39)$ & $(0.36)$ & $(0.47)$ \\
\hline \multirow[t]{2}{*}{ Interest in politics } & -0.29 & 0.45 & 0.09 & -0.70 \\
\hline & $(0.40)$ & $(0.43)$ & $(0.41)$ & $(0.52)$ \\
\hline \multirow[t]{2}{*}{ Left-right } & 2.37 & $8.67 *$ & -0.68 & $11.05^{*}$ \\
\hline & $(2.92)$ & (3.69) & $(2.74)$ & $(4.57)$ \\
\hline \multirow[t]{2}{*}{ Left-right $^{2}$} & -2.91 & $-6.99 \#$ & 0.41 & $-14.06^{* *}$ \\
\hline & $(3.32)$ & (3.70) & $(3.20)$ & $(4.84)$ \\
\hline \multirow[t]{2}{*}{ Satisfaction with democracy AT } & 0.59 & 0.53 & -0.05 & -0.38 \\
\hline & $(0.46)$ & $(0.38)$ & $(0.38)$ & $(0.52)$ \\
\hline \multirow[t]{2}{*}{ Satisfaction with democracy EU } & -0.16 & $1.37 * *$ & -0.43 & 1.02 \\
\hline & $(0.43)$ & $(0.42)$ & $(0.40)$ & $(0.65)$ \\
\hline \multirow[t]{2}{*}{ Satisfaction with government AT } & $-1.45 * *$ & 0.38 & -1.05 & $-1.66 \#$ \\
\hline & $(0.51)$ & $(0.48)$ & $(0.65)$ & $(0.92)$ \\
\hline \multirow[t]{2}{*}{ Satisfaction with decisions of EU (past 12 month) } & -0.40 & 0.30 & $-0.85 \#$ & $1.93^{*}$ \\
\hline & $(0.45)$ & $(0.40)$ & $(0.45)$ & $(0.85)$ \\
\hline \multirow[t]{2}{*}{ Assessment of European integration } & -0.05 & 0.04 & $-0.17 *$ & $0.39 * * *$ \\
\hline & $(0.08)$ & $(0.07)$ & $(0.07)$ & $(0.09)$ \\
\hline \multirow[t]{2}{*}{ AT should support other EU members } & -0.13 & 0.22 & -0.09 & -0.03 \\
\hline & $(0.21)$ & $(0.20)$ & $(0.19)$ & $(0.26)$ \\
\hline \multirow[t]{2}{*}{ Changes in Economic Situation AT (past 12 month) } & -0.24 & -0.06 & -0.30 & 0.12 \\
\hline & $(0.22)$ & $(0.21)$ & $(0.21)$ & $(0.35)$ \\
\hline \multirow[t]{2}{*}{ Constant } & -1.23 & $-5.93 * * *$ & -0.84 & $-4.44 * *$ \\
\hline & $(0.92)$ & $(1.18)$ & $(0.85)$ & $(1.56)$ \\
\hline$N$ & 223 & 407 & 394 & 231 \\
\hline Cragg-Uhler $\mathrm{R}^{2}$ & 0.23 & 0.26 & 0.24 & 0.56 \\
\hline
\end{tabular}

Note: Standard errors in parentheses; \# $\mathrm{p}<.10,{ }^{*} \mathrm{p}<.05,{ }^{* *} \mathrm{p}<.01,{ }^{* * *} \mathrm{p}<.001 ;{ }^{1}$ Government parties = SPÖ, ÖVP; Opposition parties = FPÖ, Greens, NEOS; ${ }^{2}$ Pro-EU parties = SPÖ, ÖVP, Greens, NEOS, Piraten; Anti-EU parties = FPÖ, BZÖ, Europa Anders, REKOS, EUStop; See Tables $\mathrm{A} 1$ and $\mathrm{A} 2$ in the Appendix for the variable coding.

Table 3. Electoral behavior at EP election compared to national election: Hypotheses.

\begin{tabular}{|c|c|c|c|}
\hline \multirow{4}{*}{ Turnout } & Abstention more likely in EP elections & $\mathrm{H} 1$ & $\checkmark$ \\
\hline & ...EU support increases turnout at EP elections & $\mathrm{H3}$ & $\checkmark$ \\
\hline & ....interest and involvement increases turnout at EP elections & $\mathrm{H} 4$ & $\approx$ \\
\hline & Abstention more likely amongst voters of (large) government parties & $\mathrm{H} 2 \mathrm{~b}$ & $x$ \\
\hline \multirow{5}{*}{ Vote Change } & Vote switch from (large) government party to (small) opposition party & $\mathrm{H} 2 \mathrm{a}$ & $\checkmark$ \\
\hline & ...increases with dissatisfaction with national politics & H5 & $\checkmark$ \\
\hline & ...increases with dissatisfaction with European politics & $\mathrm{H} 7 \mathrm{a}$ & $x$ \\
\hline & ...is based on ideological predispositions & H6 & $x$ \\
\hline & $\begin{array}{l}\text { Vote switch from pro-European party to Eurosceptic party increases with dissatisfaction } \\
\text { with European politics }\end{array}$ & $\mathrm{H} 7 \mathrm{~b}$ & $\checkmark$ \\
\hline
\end{tabular}

\section{Discussion}

This study set out to test the second order elections framework (Reif \& Schmitt, 1980) in the context of the most recent 2014 EP election in Austria. The different context of this election gave rise to speculations to what degree the second-order framework would still apply. Notably, and in addition to considering whether voting patterns would be in line with the second-order framework, our study addresses the motivation for an 
individual's differential voting behavior at national versus EP elections. By and large, we still find indications of the second-order framework regarding the 2014 EP elections. On the aggregate-level, we indeed see that citizens were less inclined to turn out at the EP election than at the national election, and that there is a tendency towards an anti-government swing (Marsh, 1998). Thus, our findings confirm the basic assumptions of the second-order framework, namely that people defect and that they rather vote for (smaller) opposition parties than for the (bigger) government parties. These aggregate-level findings are in line with Träger (2015) who provides evidence across EU member states that points into a similar direction for the 2014 election (see also Freire \& Pereira, 2015, for the Portuguese case).

In a second step, we consider whether individuals' motivations for second-order voting are also in line with the assumptions from the general framework. We find that to be the case in particular for vote switching from government to opposition parties, which appears to be strongly driven by discontent with the national government. It is therefore not the case that voters refrain from strategic votes for big parties and rather 'go with their hearts' along their political predispositions, but rather that small opposition parties win, because people 'vote with their boots', as they want to punish the incumbent (e.g. van der Eijk et al., 1996). Only further specifications of the vote switch between the national and EP election give some indication for an 'EU matters' framework on the one hand, and for a 'voting with the heart' on the other. When considering vote switches from rather pro-EU or government parties in national elections to anti-EU or populist parties in the EP elections, we see a clear influence of EU attitudes as a motivation. Furthermore, and rather to our surprise, political predispositions in the form of ideology mattered only for vote switches that were in contrast to what the second-order framework would postulate. In sum, when considering the general assumptions of the second-order framework, we only find the motive of protest to stand out for vote switching.

Concerning turnout patterns, we see a role of both, political involvement and EU attitudes, with those paying attention to politics and those with positive EU attitudes being more likely to turn out at EP elections, or less likely to abstain after having voted in national elections. Involvement seems to play a considerable role as well. This is somewhat in line with Söderlund et al. (2011) who suggest a strong role for political involvement in explaining second-order election turnout. Concerning both turnout and vote choice patters, we see that further specifying the basic postulates of the second-order framework to certain parties was important for finding at least some support for an 'EU matters' framework. In sum, we find indications of second-order voting and these are driven by political involvement regarding turnout, and by protest regarding vote switches. Our results give little reason to doubt that the second-order framework persisted to be applicable to the 2014 EP election, at least in Austria.

A real asset of our study is the database it draws upon. Using survey responses from a panel in which the same individuals were probed directly following the national and the EP election is a clear improvement compared to the designs of many prior studies that relied on either macro-level analysis or hypothetical survey questions regarding vote choice in a far-away election. While Austria is a good case to study the secondorder framework, being a rather typical European multiparty system, one problem remains. Austria was ruled by a grand coalition comprised of the country's two major parties in 2014 when the EP election was held. Therefore, our study of the second-order framework was not able to distinguish between government and large parties on the one hand, and opposition and small parties on the other. Our analysis of vote choice is a combination of both, and we are thus not able to see whether large vs. small party voting would be motivated by something else than protest.

Furthermore, Marsh (1998) has shown that secondorder voting patterns were more pronounced in countries in which government alternation was the norm, rather than the exception. Austria, however, is characterized by strong stability in terms of government. This may be an explanation why the patterns we identified were present, but not dramatic. One can speculate that the findings would be more pronounced in other countries where governments are more likely to change from one national election to the next. Another point worthy of stressing here is that our study explicitly aimed at studying patters of changes in voting behavior between national and EP elections and the motivations for such changes. Therefore, we do not attempt to answer the question whether EU attitudes were more important as a predictor of vote choice for certain parties at EP elections compared to national elections, but merely whether they mattered for changing the vote. Extensions of our study to other times and contexts should make sure that identical vote choice models can be built to address this question.

A final limitation relates to the fact that we could not empirically address the question whether the 2014 EP election was more or less second-order compared to previous elections. Overall, the findings are in line with expectations derived from the framework, and therefore we conclude that the Austrian EP election 2014 still had clear signs of second-orderness despite an economic crisis at center stage and a strongly personalized campaign.

\section{Acknowledgments}

This research is conducted under the auspices of the 
Austrian National Election Study (AUTNES), a National Research Network (NFN) sponsored by the Austrian Science Fund (FWF) (S10902-G11). We are grateful to Johann Gründl for his research assistance as well as the two anonymous referees for helpful comments. All authors contributed equally, authorship is in alphabetical order.

\section{Conflict of Interests}

The authors declare no conflict of interests.

\section{References}

Blais, A. (2006). What affects voter turnout? Annual Review of Political Science, 9, 111-125.

Blondel, J., Sinnott, R., \& Svensson, P. (1997). Representation and voter participation. European Journal of Political Research, 32(2), 243-272.

Boomgaarden, H. G., \& de Vreese, C. H. (2016). Do European elections create a European public sphere? In W. van der Brug \& C. H. de Vreese (Eds.), (Un)intended consequences of European Parliament elections. Oxford: Oxford University Press.

Brunsbach, S., John, S., \& Werner, A. (2012). The supply side of second-order elections: Comparing German national and European election manifestos. German Politics, 21(1), 91-115.

Carrubba, C., \& Timpone, R. J. (2005). Explaining vote switching across first- and second-order elections evidence from Europe. Comparative Political Studies, 38(3), 260-281.

Clark, N., \& Rohrschneider, R. (2009). Second-Order Elections versus First-Order Thinking: How Voters Perceive the Representation Process in a Multi-Layered System of Governance. Journal of European Integration, 31(5), 645-664.

Curtice, J. (1989). The 1989 European Election: Protest or green tide? Electoral Studies, 8(3), 217-230.

Cushion, S., \& Thomas, R. (2015). Reporting different second order elections: A comparative analysis of the 2009 and 2013 local and EU elections on public and commercial UK television news bulletins. British Politics. doi:10.1057/bp.2015.26

De Vreese, C. H. (2003). Television reporting of secondorder elections. Journalism Studies, 4(2), 183-198.

De Vreese, C. H. (2009). Second-rate election campaigning? An analysis of campaign styles in European parliamentary elections. Journal of Political Marketing, 8(1), 7-19.

De Vreese, C., \& Tobiasen, M. (2007). Conflict and identity: Explaining turnout and anti-integrationist voting in the Danish 2004 elections for the European Parliament. Scandinavian Political Studies, 30(1), 87-114.

Denny, K., \& Doyle, O. (2008). Political interest, cognitive ability and personality: Determinants of voter turnout in Britain. British Journal of Political Science,
38(2), 291-310.

Flickinger, R. S., \& Studlar, D. T. (2007). One Europe, many electorates? Models of turnout in European Parliament elections after 2004. Comparative Political Studies, 40(4), 383-404.

Franklin, M. N., \& Wlezien, C. (1997). The responsive public issue salience, policy change, and preferences for European unification. Journal of Theoretical Politics, 9(3), 347-363.

Franklin, M. N., van der Eijk, C., \& Marsh, M. (1995). Referendum outcomes and trust in government: Public support for Europe in the wake of Maastricht. West European Politics, 18(3), 101-117.

Freire, A. (2004). Second-order elections and electoral cycles in democratic Portugal. South European Society and Politics, 9(3), 54-79.

Freire, A., \& Pereira, J. S. (2015). More second-order than ever? The 2014 European Election in Portugal. South European Society and Politics, 20(3), 381-401.

Giebler, H., \& Wagner, A. (2015). Contrasting first- and second-order electoral behaviour: determinants of individual party choice in European and German federal elections. German Politics, 24(1), 46-66.

Hanmer, M. J., \& Kalkan, K. O. (2013). Behind the curve: Clarifying the best approach to calculating predicted probabilities and marginal effects from limited dependent variable models. American Journal of Political Science, 57(1), 263-277.

Heath, A., McLean, I., Taylor, B., \& Curtice, J. (1999). Between first and second order: A comparison of voting behaviour in European and local elections in Britain. European Journal of Political Research, 35(3), 389-414.

Hix, S., \& Marsh, M. (2007). Punishment or protest? Understanding European parliament elections. Journal of Politics, 69(2), 495-510.

Hix, S., \& Marsh, M. (2011). Second-order effects plus pan-European political swings: An analysis of European Parliament elections across time. Electoral Studies, 30(1), 4-15.

Hobolt, S. B., Spoon, J. J., \& Tilley, J. (2009). A vote against Europe? Explaining defection at the 1999 and 2004 European Parliament elections. British Journal of Political Science, 39(1), 93-115.

Koepke, J. R., \& Ringe, N. (2006). The second-order election model in an enlarged Europe. European Union Politics, 7(3), 321-346.

Kritzinger, S., Johann, D., Glantschnigg, C., Aicholzer, J., Glinitzer, K., Thomas, K., \& Wagner, M. (2016). AUTNES Online Panel Study. GESIS Data Archive.

Marsh, M. (1998). Testing the second-order election model after four European elections. British Journal of Political Science, 28(4), 591-607.

Marsh, M. \& Mikhaylov, S. (2008). European Parliament elections as second order national elections: A review of the evidence. Retrieved from http://europe angovernance.livingreviews.org

Mattila, M. (2003). Why bother? Determinants of turn- 
out in the European elections. Electoral studies, 22(3), 449-468.

McAllister, L. (2004). Steady state or second order? The 2003 elections to the National Assembly for Wales. The Political Quarterly, 75(1), 73-82.

Niedermayer, O. (1990). Turnout in the European Elections. Electoral Studies, 9, 45-50.

Piedrafita, S., \& Renman, V. (2014). The 'personalisation' of the European Elections: A half-hearted attempt to increase turnout and democratic legitimacy? (EPIN Papers, 37). Brussels: Centre for European Policy Studies.

Reif, K. (1984). National electoral cycles and European elections 1979 and 1984. Electoral Studies, 3(3), 244255.

Reif, K., \& Schmitt, H. (1980). Nine second-order national elections: A conceptual framework for the analysis of European election results. European Journal of Political Research, 8(1), 3-44.

Reif, K., \& Schmitt, H. (1997). Second-order elections. European Journal of Political Research, 31(1/2), 109124.

Schakel, A. H., \& Jeffery, C. (2013). Are regional elections really 'second-order' elections? Regional Studies, 47(3), 323-341.

Schmitt, H. (2005). The European Parliament Elections of June 2004: Still second-order? West European Politics, 28(3), 650-679.

Schmitt, H., \& Mannheimer, R. (1991). About voting and non-voting in the European elections of June 1989. European Journal of Political Research, 19(1), 31-54.

Söderlund, P., Wass, H., \& Blais, A. (2011). The impact of motivational and contextual factors on turnout in first-and second-order elections. Electoral studies, 30(4), 689-699.

Tenscher, J., \& Maier, M. (2009). European Parliamentary elections 2004: Studies on political campaigning and media framing of a second-order event. Journal of Political Marketing, 8(1), 1-6.

Träger, H. (2015). Die Europawahl 2014 als second-order election. In Die Europawahl 2014 (pp. 33-44). Wiesbaden: Springer Fachmedien.

Van Aelst, P., \& Lefevere, J. (2012). Has Europe got anything to do with the European elections? A study on split-ticket voting in the Belgian regional and European elections of 2009. European Union Politics, 13(1), 3-25.

Van der Eijk, C., \& Franklin, M. N. (1996). Choosing Europe? The European electorate and national politics in the face of union. Michigan: University of Michigan Press.

Van der Eijk, C., Franklin, M., \& Marsh, M. (1996). What voters teach us about Europe-wide elections: What Europe-wide elections teach us about voters. Electoral Studies, 15(2), 149-166.

Van der Eijk, C., \& Niemöller, B. (2008). Recall accuracy and its determinants. In: K. Arzheimer \& J. Evans (eds.), Electoral Behavior. Debates and Methodology (pp. 232-280). Los Angeles: Sage.

Van der Eijk, C., \& Oppenhuis, E. (1990). Turnout and second-order effects in the European elections of June 1989: Evidence from the Netherlands. Acta Politica, 25, 67-94.

Waldahl, R., \& Aardal, B. (2000). The accuracy of recalled previous voting: evidence from the Norwegian election study. Scandinavian Political Studies, 23(4), 373389.

Weir, B. T. (1975). The distortion of voter recall. American Journal of Political Science, 19(1), 53-62.

Wilke, J., \& Reinemann, C. (2007). Invisible second-order campaigns? A longitudinal study of the coverage of the European Parliamentary elections 1979-2004 in four German quality newspapers. Communications, 32(3), 299-322.

\section{About the Authors}

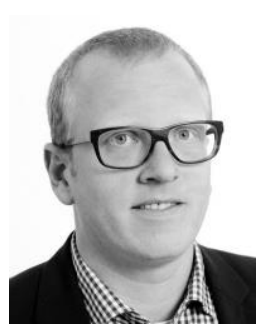

\section{Dr. Hajo Boomgaarden}

Hajo Boomgaarden is Professor of Methods in the Social Sciences with a focus on Text Analysis at the University of Vienna He held positions as Assistant and Associate Professor for Political Communication at the Amsterdam School of Communication Research and the Department of Communication at the University of Amsterdam. His research focuses broadly on political communication, with an emphasis on media and European integration, media and populist, extreme right parties, election campaigns and advancements of computerized methods of text analysis with multimedia analysis.

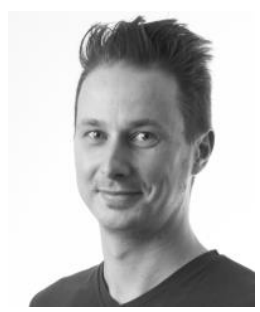

\section{Dr. David Johann}

David Johann is Senior Research Associate in the Department of Methods in the Social Sciences at the University of Vienna and a core team member of the Austrian National Election Study (AUTNES). In addition, he is Post-Doctoral Research Associate at the German Centre for Research on Higher Education and Science Studies (DZHW). David Johann completed his PhD in Political Science at the University of Vienna. 


\section{Dr. Sylvia Kritzinger}

Sylvia Kritzinger is Professor and Head of the Department of Methods in the Social Sciences at the University of Vienna. She obtained her PhD in Political Science at the University of Vienna and then held post-doc and visiting positions at Trinity College Dublin, Institute for Advanced Studies and Vienna University. Her research focuses on political behavior and electoral research, democratic representation and political participation, and quantitative methods in the social sciences. She is one of the principal investigators of the Austrian National Election Study (AUTNES) being responsible for the Demand Side. 


\section{Appendix}

Table A1. Dependent variables descriptives.

\begin{tabular}{|c|c|c|c|}
\hline Dependent Variables & $\mathbf{n}$ & Scale & $\%$ \\
\hline \multirow[t]{4}{*}{ Turnout $^{1}$} & 1218 & 1 & 7.64 \\
\hline & & 2 & 24.30 \\
\hline & & 3 & 1.64 \\
\hline & & 4 & 66.42 \\
\hline \multirow[t]{2}{*}{ Vote Choice: ${ }^{2}$ Opposition to Government } & 479 & 0 & 86.43 \\
\hline & & 1 & 13.57 \\
\hline \multirow[t]{2}{*}{ Vote Choice: Government to Opposition } & 272 & 0 & 74.26 \\
\hline & & 1 & 25.74 \\
\hline \multirow[t]{2}{*}{ Vote Choice: Pro-EU to Anti-EU } & 475 & 0 & 87.37 \\
\hline & & 1 & 12.63 \\
\hline \multirow[t]{2}{*}{ Vote Choice: Anti-EU to Pro-EU } & 269 & 0 & 74.35 \\
\hline & & 1 & 25.65 \\
\hline
\end{tabular}

Note: ${ }^{1}$ Turnout: $1=$ abstaining from both elections $(n=93) ; 2=$ participating only in the national election ( $\left.n=296\right)$; $3=$ participating only in EP elections ( $n=20)$; $4=$ participating both in the national and the EP elections ( $n=809) ;{ }^{2}$ For all vote choice variables: $0=$ staying with the same party as in the national election; $1=$ switching to a different party.

Table A2. Independent variables descriptives.

\begin{tabular}{|c|c|c|c|c|c|}
\hline Independent variables & $\mathbf{n}$ & mean & SD & $\min$ & $\max$ \\
\hline Age 16 to 29 & 1222 & 0.16 & 0.37 & 0 & 1 \\
\hline Age 30 to 44 & 1222 & 0.29 & 0.45 & 0 & 1 \\
\hline Age 45 to 59 & 1222 & 0.34 & 0.47 & 0 & 1 \\
\hline Men & 1222 & 0.49 & 0.50 & 0 & 1 \\
\hline Education (Matura) & 1214 & 0.50 & 0.50 & 0 & 1 \\
\hline Interest in politics & 1216 & 0.64 & 0.48 & 0 & 1 \\
\hline Left-right & 1075 & 0.48 & 0.21 & 0 & 1 \\
\hline Left-right $^{2}$ & 1075 & 0.27 & 0.21 & 0 & 1 \\
\hline Satisfaction with democracy AT & 1187 & 0.56 & 0.50 & 0 & 1 \\
\hline Satisfaction with democracy EU & 1155 & 0.38 & 0.49 & 0 & 1 \\
\hline Satisfaction with government AT & 1181 & 0.14 & 0.35 & 0 & 1 \\
\hline Satisfaction with decisions of EU (past 12 month) & 1123 & 0.25 & 0.43 & 0 & 1 \\
\hline Assessment of European integration & 1141 & 4.15 & 3.01 & 0 & 10 \\
\hline AT should support other EU members & 1189 & -0.42 & 1.12 & -2 & 2 \\
\hline Changes in Economic Situation AT (past 12 month) & 1197 & -0.59 & 0.92 & -2 & 2 \\
\hline Attentiveness to general election campaign & 1018 & 0.59 & 0.49 & 0 & 1 \\
\hline Attentiveness to EP election campaign & 1220 & 0.50 & 0.50 & 0 & 1 \\
\hline
\end{tabular}

Note: The exact question wording for all variables can be found in the AUTNES codebook on www.autnes.at 
Table A3. Multinomial logit model explaining turnout (Baseline category: Turnout in No Election).

\begin{tabular}{|c|c|c|c|}
\hline & $\begin{array}{l}\text { Turnout Only in } \\
\text { General Election }\end{array}$ & $\begin{array}{c}\text { Turnout Only in EP } \\
\text { Election }\end{array}$ & $\begin{array}{l}\text { Turnout in Both } \\
\text { Elections }\end{array}$ \\
\hline Age 16 to 29 & $\begin{array}{l}-0.15 \\
(0.73)\end{array}$ & $\begin{array}{c}1.19 \\
(1.45)\end{array}$ & $\begin{array}{l}-0.97 \\
(0.70)\end{array}$ \\
\hline Age 30 to 44 & $\begin{array}{l}-0.06 \\
(0.58)\end{array}$ & $\begin{array}{c}1.51 \\
(1.23)\end{array}$ & $\begin{array}{l}-0.71 \\
(0.54)\end{array}$ \\
\hline Age 45 to 59 & $\begin{array}{l}-0.40 \\
(0.55)\end{array}$ & $\begin{array}{c}0.50 \\
(1.21)\end{array}$ & $\begin{array}{l}-0.75 \\
(0.51)\end{array}$ \\
\hline Men & $\begin{array}{l}-0.46 \\
(0.36)\end{array}$ & $\begin{array}{l}-0.47 \\
(0.65)\end{array}$ & $\begin{array}{c}0.01 \\
(0.34)\end{array}$ \\
\hline Education (Matura) & $\begin{array}{c}0.43 \\
(0.40)\end{array}$ & $\begin{array}{c}0.63 \\
(0.68)\end{array}$ & $\begin{array}{l}0.98^{* *} \\
(0.38)\end{array}$ \\
\hline Interest in politics & $\begin{array}{c}0.89 * \\
(0.44)\end{array}$ & $\begin{array}{c}0.34 \\
(0.78)\end{array}$ & $\begin{array}{c}\text { 0.84* } \\
(0.41)\end{array}$ \\
\hline Left-right & $\begin{array}{c}1.29 \\
(3.41)\end{array}$ & $\begin{array}{l}-1.62 \\
(5.43)\end{array}$ & $\begin{array}{l}-3.66 \\
(3.11)\end{array}$ \\
\hline Left-right $^{2}$ & $\begin{array}{l}-0.83 \\
(3.03)\end{array}$ & $\begin{array}{l}-0.60 \\
(5.65)\end{array}$ & $\begin{array}{c}3.48 \\
(2.77)\end{array}$ \\
\hline Satisfaction with democracy AT & $\begin{array}{c}0.29 \\
(0.40)\end{array}$ & $\begin{array}{c}0.54 \\
(0.74)\end{array}$ & $\begin{array}{c}0.42 \\
(0.38)\end{array}$ \\
\hline Satisfaction with democracy EU & $\begin{array}{c}0.42 \\
(0.56)\end{array}$ & $\begin{array}{c}1.10 \\
(0.86)\end{array}$ & $\begin{array}{c}0.86 \\
(0.53)\end{array}$ \\
\hline Satisfaction with government AT & $\begin{array}{c}0.20 \\
(0.65)\end{array}$ & $\begin{array}{l}-0.82 \\
(1.26)\end{array}$ & $\begin{array}{l}-0.24 \\
(0.63)\end{array}$ \\
\hline Satisfaction with decisions of EU (past 12 month) & $\begin{array}{l}1.17 \\
(0.84)\end{array}$ & $\begin{array}{c}0.66 \\
(1.18)\end{array}$ & $\begin{array}{l}1.68 * \\
(0.81)\end{array}$ \\
\hline Assessment of European integration & $\begin{array}{c}0.00 \\
(0.08)\end{array}$ & $\begin{array}{c}0.10 \\
(0.13)\end{array}$ & $\begin{array}{c}0.03 \\
(0.08)\end{array}$ \\
\hline AT should support other EU members & $\begin{array}{l}-0.05 \\
(0.21)\end{array}$ & $\begin{array}{c}0.06 \\
(0.35)\end{array}$ & $\begin{array}{l}0.04 \\
(0.19)\end{array}$ \\
\hline Changes in Economic Situation AT (past 12 month) & $\begin{array}{l}-0.14 \\
(0.23)\end{array}$ & $\begin{array}{l}-1.11^{*} \\
(0.46)\end{array}$ & $\begin{array}{l}-0.22 \\
(0.21)\end{array}$ \\
\hline Attentiveness to general election campaign & $\begin{array}{c}0.78 \# \\
(0.44)\end{array}$ & $\begin{array}{c}0.23 \\
(0.77)\end{array}$ & $\begin{array}{l}0.65 \\
(0.41)\end{array}$ \\
\hline Attentiveness to EP election campaign & $\begin{array}{l}-0.60 \\
(0.43)\end{array}$ & $\begin{array}{c}0.78 \\
(0.72)\end{array}$ & $\begin{array}{l}0.86 * \\
(0.39)\end{array}$ \\
\hline Constant & $\begin{array}{l}-0.09 \\
(1.16)\end{array}$ & $\begin{array}{l}-3.53 \# \\
(1.98)\end{array}$ & $\begin{array}{c}1.39 \\
(1.07)\end{array}$ \\
\hline$N$ & 763 & & \\
\hline
\end{tabular}

